\title{
Robotik, Kodlama ve Elektronik ile İlgili Yapılan Ders Dışı Uygulama Durumlarının Tespit Edilmesi İle İlgili Öğretmen Görüşleri
}

\section{Reyhan Öz Yıldız ${ }^{1}$ \\ Seyide Senanur Talaslığlu \\ Doç. Dr. Mehtap Yıldırım ${ }^{3 *}$}

Geliş tarihi: 03.04.2020

Kabul tarihi: 08.05.2020

\section{Atuf bilgisi: \\ IBAD Sosyal Bilimler Dergisi \\ Sayı: $8 \quad$ Sayfa: 193-208}

Yıl: 2020 Dönem: Güz

This article was checked by Turnitin. Similarity Index 5\%

Bu makalede araştırma ve yayın etiğine uyulmuștur.

${ }^{1}$ Marmara University, Turkey, ozz.reyhan@gmail.com,

ORCID ID 0000-0003-2976-5931

${ }^{2}$ Marmara University, Turkey, senatalas@gmail.com,

ORCID ID 0000-0001-7019-7062

${ }^{3}$ Marmara University, Turkey, mehtap.yildirim@marmara.edu.tr,

ORCID ID 0000-0001-7398-8396

\footnotetext{
* Sorumlu yazar
}

ÖZ

Araştırmada robotik, kodlama ve elektronik ile ilgili okulda yapılan ders dıșı uygulamaların tespit edilmesi ve robotik, kodlama ve elektronik uygulamalarla ilgili çeșitli konularda öğretmen görüşlerinin belirlenmesi amaçlanmıștır. $\mathrm{Bu}$ araștırma kapsamında veriler çevrimiçi bir görüşme formu yardımıyla İstanbul ili Avcılar ilçesinde bulunan 52 devlet okulundan öğretmen veya idareciler aracılığıyla toplanmıştır. Çalışmada elde edilen verilerin incelenmesi için nitel veri analiz yöntemlerinden olan betimsel analiz kullanılmıştır. Elde edilen sonuçlar; mevcut durum tespiti, okulların ihtiyaç durumları, okulların gelecek planları ve robotik kodlama ve elektronik uygulamalarının eğitime olan katkısı çerçevesinde analiz edilmiștir. Araştırma sonuçlarına bakıldığında, okulların robotik, kodlama ve elektronik uygulamaları formal eğitim kapsamında değil daha çok ders dışı aktiviteler şeklinde gerçekleştirdikleri ve son iki yılda buna ağırlık verdikleri ortaya çıkarılmıştır. Ayrıca, öğretmenler, bu tip uygulamaların, öğrencilerin üst düzey becerilerini geliştirdiği ve okula karşı ilgiyi ve farkındalığı artırdığı yönünde görüş belirtmişlerdir.

Anahtar Kelimeler: robotik, kodlama, elektronik, öğretmen görüşleri. 


\title{
Determination of Situations of Extra-curricular Practices Carried About Robotics, Coding and Electronics
}

\author{
Reyhan Öz Yıldız ${ }^{1}$ \\ Seyide Senanur Talaslığlu² \\ Assoc. Prof. Dr. Mehtap Yıldırım ${ }^{3 *}$
}

First received: 03.04 .2020

Accepted: 08.05.2020

\section{Citation:}

IBAD Journal of Social Sciences

Issue: 8

Pages: 193-208

Year: 2020

Session: Fall

This article was checked by Turnitin. Similarity Index 5\%

${ }^{1}$ Marmara University, Turkey, ozz.reyhan@gmail.com, ORCID ID 0000-0003-2976-5931

2Marmara University, Turkey, senatalas@gmail.com,

ORCID ID 0000-0001-7019-7062

${ }^{3}$ Marmara University, Turkey, mehtap.vildirim@marmara.edu.tr,

ORCID ID 0000-0001-7398-8396

\footnotetext{
* Corresponding Author
}

\begin{abstract}
In this study, it was aimed to determine the extracurricular practices in the school related to robotics, coding and electronics and to determine the view of teachers about these practices. Within the context of this study, the data were collected from teachers or administrators from 52 public schools in Avc1lar district of Istanbul province, using an online interview form. Descriptive analysis, one of the qualitative data analysis methods, was used to examine the data obtained from the study. Obtained results were analyzed within the framework of the determination of current status, the determination of schools' requirements, future plans of schools and the contribution of robotics - coding and electronic applications to education. In addition, teachers stated that such practices improve students' high-level skills and increase interest and awareness towards the school.
\end{abstract}

Keywords: robotics, coding, electronics, teacher views 


\section{INTRODUCTION}

Human being continues to learn throughout the life. There is education just behind learning. Education strengthens its continuity by affecting people, those who are in his/her environment and the world in which person lives as well. Although individuals live with the knowledge they have acquired in their past, they continue to produce mental ideas for their future. Not only individuals but also everything in the world changes and improves. Therefore, education continues to change and advance by new quests. Educators state that new emergent quests and approaches are connected with the $21^{\text {st }}$ century skills (Gelen, 2017).

Some of the $21^{\text {st }}$ century's competencies are known as technological literacy, computational thinking and programming skills (EARGED, 2011; Eguchi, 2012; Turiman, Omar, Daud, \& Osman, 2012). One of the applicable education fields with its counterpart that support improving of these skills is practice of robotics and coding (Pinto \& Escudeiro, 2014; Kasalak, 2017). Robotics and coding education requires an interdisciplinary study. While robotics discusses the working principles, design or usage of technological devices; coding contains the practice and improvement process of instruction systems in order to provide the interaction between human being and technology (Sayın \& Seferoğlu, 2016). Robotics and coding definitions are applicable to life problems and when combined with producing effective solutions, the number of discipline that they affect increases and the interdisciplinary connections gets stronger. Elkind (2008) states that educational robotics studies enable students to understand the effects of improving technology and to examine scientific concepts. Robotic and coding practices that combine different disciplines in educational systems can contribute to the acquisition of $21^{\text {st }}$ century skills.

Education systems are tried to be improved by considering that coding based robotics practices Learn by the children at an early age (Göksoy \& Y1lmaz, 2018). In our country, it has been aimed that individuals start coding learning at an early age in making informatics technology and software lesson at $5^{\text {th }}$ and $6^{\text {th }}$ classes that is compulsory since 2013 (MoNE, 2018). In secondary school, on the other hand, education program targeted that student's gain robotics programming skills of "Level 1" and "Level 2" at the computer lessons applied (MoNE, 2018). Learning coding means learning the working principles of our current technological devices, being able to use them and producing for better. Giving robotics and coding education to students is an important step since they will be technology improvers of the future.

When literature is examined, it is seen that studies regarding robotics and coding have increased at the last period and it was found that they have positive impacts in terms of different skills (Şenol \& Büyük, 2015; Kasalak, 2017; Sirakaya, 2018) and teachers' accessing to $21^{\text {st }}$ century skills and leading to students in this way are important matters. Basic robotics and coding skills are not a matter that only computer teachers need to get (Kay, Moss, Engelman \& McKlin, 2014). Teachers from almost every branch who are interested in this field in direction of interdisciplinary studies' requirements can support student's development. Nevertheless, it is also necessary to raise awareness of teachers and to meet requirements of students and teachers such as place, material etc.

Studies that are to be practiced or expected to be practiced regarding robotics and coding at schools might be seen as a difficult, challenging process for teachers. However, at the end of studies they carried, it was observed that this kind of anxiety has disappear, the information chaos that constitutes fear has decreased and they have carried practices in an enjoyable manner as teachers gain experience (Kay \& Moss, 2012; Şişman \& Küçük, 2018). Therefore, that experienced teachers take part constituting school ecosystem and at the same time, it is an important issue that these teachers support educationally in order to carry out robotic-coding studies with their students in or out of the class. However, robotics and coding educations do not only depend on the existence of teachers' experience. In this process, school, student, teacher and material (robot) should be considered as a whole. Setting a budget for infrastructure of school and getting necessary materials, the level of students' requests and foreknowledge, the suitability of material that is used to the level of student and its durability are required specifications (Alsoliman, 2018). However, since schools do not have necessary expert supports or funds for improving exciting programs like robotic-coding, problems arise in robotic- 
coding education and this situation prevents the demonstration of required importance for this field (Ettershank, Nel \& Solms, 2017).

In this context, the aim of this study is to offer suggestions for increasing robotics, coding and electronics applications by determination the qualifications of robotics, coding and electronics practices applied at schools. In addition to determine how often these studies apply at schools, the programs used during studies, future plans of schools regarding coding, robotics and electronics and also contribution of these practices to education system.

The research question is "What are the robotic, coding and electronic applications in extracurricular and what their educational contribution is?"

In frame of determined problem, answers are sought to the Sub- research questions are;

- How is the current situation regarding coding, robotics and electronics at schools?

- What are the needs of schools, students and teachers regarding coding, robotics and electronics practices?

- What are the suggestions to schools, teachers and students to make extracurricular practices regarding coding, robotics and electronics to be more effective?

- What are the teachers' views about of practices of coding, robotics and electronics?

\section{METHOD}

\section{Research Design}

This research is a case study. Case studies aim to find out how the factors related to a situation affect the case or how they are affected by a holistic approach (Yıldırım \& Şimşek, 2008). The case examined in this research is what robotic, electronic and coding practices are performed in formal schools and how they are realized. To determine this, the views of teachers and administrators were asked with the help of a questionnaire. Consequently, this study is a research in which a certain case is detected in a certain time.

\section{Study Group}

The study group of the research consists of teachers and administrators working in state schools in Avcilar district of Istanbul in 2018-2019 academic year. The study group included in the research was chosen through convenience sampling. Because one of the researchers works in this district. Convenience sampling is created by selecting a situation that is close to it and easy to reach in order to give the researcher work speed and practicality (Yıldırım \& Şimşek, 2008).The questions in data collection tool used in the research have been shared as online at 2018-2019 academic year first semester and answered by teachers who carried coding-robotics and electronics studies at all rank of schools. In addition, some schools do not have teachers who carry out these studies. In that case, one of the school administrators was asked to answer the questionnaire. At the result, 52 schools in total participated in the research as 4 pre-schools, 14 primary schools, 18 secondary schools and 16 high schools. The questionnaire was answered by administrator in 36 schools and by teacher who carried out the practice in 16 schools. The schools in the research were given codes such as school $1\left(\mathrm{Sch}_{1}\right)$, school $2\left(\mathrm{Sch}_{2}\right)$ etc.

\section{Data Collection Tools}

In this research, for data collection, a questionnaire was used.

\section{School Coding-Robotics Studies Questionnaire}

"School Robotics-Coding Studies Questionnaire" used in the research consists of two closed-ended and eight open ended questions.

Interview questions were prepared toward to positive and negative situations that might be experienced by educators. The validity of interview questions was ensured by receiving opinion from 
other researchers who study in the field and experts. A Turkish teacher and a computer engineer who carries coding carried controls of writing and spelling mistakes of form and robotics studies, two sciences teachers and a computer teacher controlled scientific accuracy. Before research, this form was applied to 20 teachers out of sample as a pilot study. From the feedback of the teachers, it was concluded that the questionnaire was understood and suitable for its purpose. According to Özden and Durdu (2016), the increasing of the number of researcher has an important role for reliability at the stage of collecting data.

Data was collected with data collection tool prepared as online. Each school was asked to answer the questionnaire. If there is no teacher practicing at the school, the administrators are provided to answer the questionnaire. The questions below were asked to the participants:

\section{Part 1: The Determination of Current State}

$\checkmark$ Which one/s of extracurricular practices stated below is/are carried at your school?

$\checkmark$ Which one/s of extracurricular fields stated below do/es exist at your school.

$\checkmark$ Are studies of robotic-coding and electronics being carried at your schools? If they are, when did you begin to these studies?

$\checkmark$ Did teacher at your school receive any education regarding robotic-coding and electronics?

$\checkmark$ What are the branches of teachers who carry out robotics - coding - electronic studies in your school?

$\checkmark$ If the practices of robotic-coding and electronics cannot be carried at your school, what are the reasons for this?

$\checkmark$ What are the coding program and electronic and robotic tools used at your school?

\section{Part 2: The Determination of Schools' Needs}

What are your school's expectations from Directorate of National Education (DoNE) in your district in terms of practices of robotic-coding and electronics?

\section{Part 3: The Determination of Schools' Plans}

$\checkmark$ What are teachers' plans who participate in the study in terms of robotics, coding and electronics?

\section{Part 4: The Contribution of the Practices of Robotic-Coding and Electronics to Education}

$\checkmark$ In your opinion, what is the contribution of practices of robotic-coding and electronics to education given at schools?

\section{Data Analysis}

Descriptive analysis, which is one of qualitative data analysis methods, was used to examine data collected in the study. In descriptive analysis, regulations are made in data by determining themes to be constituted at first-hand. In this stage, while interpretations are made about findings obtained, the findings' transfer to the readers in a regular and open manner is provided (Yıldırım \& Şimşek, 2008).

\section{FINDINGS}

In this part of study, findings reached by analysis of data obtained from questionnaire are given place.

\section{Findings about the Analysis of Current State}

Frequency of the answers regarding to the question of "which of the extracurricular practice/s is/are applied at your school?" are given at Table 1. 
Table 1. Extra-curricular activities focused on technology and applied at schools

\begin{tabular}{|c|c|c|c|c|c|}
\hline & $\begin{array}{l}\text { Preschool } \\
\text { (f) }\end{array}$ & $\begin{array}{l}\text { Primary } \\
\text { School } \\
\text { (f) }\end{array}$ & $\begin{array}{l}\text { Secondary } \\
\text { School } \\
\text { (f) }\end{array}$ & $\begin{array}{l}\text { High School } \\
\text { (f) }\end{array}$ & $\begin{array}{l}\text { Total } \\
\text { (f) }\end{array}$ \\
\hline Robotics Education & 1 & 0 & 7 & 5 & 13 \\
\hline $\begin{array}{l}\text { Coding Education } \\
\text { Introduction } \quad \text { and } \\
\text { Awareness Raising }\end{array}$ & 1 & 3 & 9 & 6 & 19 \\
\hline $\begin{array}{l}\text { Seminars for Parents } \\
\text { and Students }\end{array}$ & & 0 & 3 & 1 & 4 \\
\hline $\begin{array}{l}\text { Extracurricular STEAM } \\
\text { Activities }\end{array}$ & & 1 & 3 & 2 & 6 \\
\hline $\begin{array}{l}\text { Total number of } \\
\text { schools }(\mathrm{N})\end{array}$ & 4 & 14 & 18 & 16 & 52 \\
\hline
\end{tabular}

According Table 1, it is seen that two school has given place to preschool technology focused on extracurricular activities. It is seen that coding education is mainly given at three schools among primary schools. While it is seen that nine schools among secondary schools mainly have given place to coding education, robotics education was given in seven schools. When the extracurricular activity rates given in high schools are examined, it is seen that coding applications are given in six schools and robotic applications are given in five schools.

Frequency of the answers regarding to the question of "Which one/s of extracurricular fields of application stated below do/es exist at your school?" are given at Table 2.

Table 2. The determination of places which schools can make extra-curricular practices

\begin{tabular}{|c|c|c|c|c|c|}
\hline & $\begin{array}{l}\text { Preschool } \\
\text { (f) }\end{array}$ & $\begin{array}{l}\text { Primary } \\
\text { School } \\
\text { (f) }\end{array}$ & $\begin{array}{l}\text { Secondary } \\
\text { School } \\
\text { (f) }\end{array}$ & $\begin{array}{l}\text { High } \\
\text { School } \\
\text { (f) }\end{array}$ & $\begin{array}{l}\text { Total } \\
\text { (f) }\end{array}$ \\
\hline $\begin{array}{l}\text { Coding-Robotics- } \\
\text { Workshop }\end{array}$ & 0 & 1 & 5 & 2 & 8 \\
\hline Support Education Room & 0 & 12 & 14 & 2 & 28 \\
\hline Computer Lab. & 0 & 2 & 13 & 10 & 25 \\
\hline Library & 0 & 8 & 14 & 15 & 37 \\
\hline Total number of schools (N) & 4 & 14 & 18 & 16 & 52 \\
\hline
\end{tabular}

According to Table 2, it is seen that there is no place at schools for making extracurricular activity at the level of preschool education. In primary schools, it is seen that support education rooms are generally used. It is also seen that coding and STEM workshops exist only at quite few schools. It is seen that Coding-Robotics-STEM workshops are more for high schools compared to other type of schools. At high schools, it is seen that mostly libraries and then computer laboratories are used for extra-curricular activity places.

Frequency of the answers regarding to the question of "Are robotics-coding-electronics studies being carried at your school? If so, when did you start these studies?” are given at Table 3. 
Table 3. Application duration of robotic-coding and electronics' practices

\begin{tabular}{llllll}
\hline & $\begin{array}{l}\text { Preschool } \\
\text { (f) }\end{array}$ & $\begin{array}{l}\text { Primary School } \\
\text { (f) }\end{array}$ & $\begin{array}{l}\text { Secondary } \\
\text { School } \\
\text { (f) }\end{array}$ & $\begin{array}{l}\text { High } \\
\text { School } \\
\text { (f) }\end{array}$ & $\begin{array}{l}\text { Total } \\
\text { (f) }\end{array}$ \\
\hline $\begin{array}{l}\text { No study carried out about } \\
\text { robotics and coding before }\end{array}$ & 3 & 10 & 8 & 10 & $\mathbf{3 2}$ \\
$\begin{array}{l}\text { Studies started to be carried at } \\
2018-2009 \text { academic year }\end{array}$ & 1 & 3 & 4 & 2 & $\mathbf{9}$ \\
$\begin{array}{l}\text { Studies have been carried for last } \\
2 \text { years or longer. }\end{array}$ & 0 & 1 & 6 & 4 & $\mathbf{1 1}$ \\
\hline Schools Carried Practices (f) & $\mathbf{1}$ & $\mathbf{4}$ & $\mathbf{1 0}$ & $\mathbf{6}$ & $\mathbf{2 0}$ \\
\hline Total number of schools (N) & $\mathbf{4}$ & $\mathbf{1 4}$ & $\mathbf{1 8}$ & $\mathbf{1 6}$ & $\mathbf{5 2}$ \\
\hline
\end{tabular}

According to Table 3, only one school conducts robotic coding applications at the preschool. The number of primary schools carrying out robotic coding applications is four, the number of secondary schools is 10 and the number of high schools is six.

Table 4 was constituted in frame of answers given to the question of "Did the teachers of your school received any education about robotic-coding and electronics?"

Table 4. The education situation of teachers about robotic-coding and electronics

\begin{tabular}{|c|c|c|c|c|c|}
\hline & $\begin{array}{l}\text { Preschool } \\
\text { f }\end{array}$ & $\begin{array}{l}\text { Primary School } \\
\text { f }\end{array}$ & $\begin{array}{l}\text { Secondary } \\
\text { School } \\
\text { f }\end{array}$ & $\begin{array}{l}\text { High } \\
\text { School } \\
\text { f }\end{array}$ & $\begin{array}{l}\text { Total } \\
\text { f }\end{array}$ \\
\hline Received Education & 0 & 5 & 8 & 6 & 19 \\
\hline Didn't Receive Education & 4 & 9 & 10 & 10 & 33 \\
\hline Total number of schools $(\mathrm{N})$ & 4 & 14 & 18 & 16 & 52 \\
\hline
\end{tabular}

In Table 4, it is seen that preschool teachers are not received education of robotics and coding, and teachers in five primary schools, eight secondary schools and six high schools receive this education.

Table 5 was showed the answers given to the question of "What are the branches of teachers who carry out robotics - coding - electronic studies in your school?"

Table 5. Branches and numbers of teachers who carry robotic-coding and electronics studies at your school.

\begin{tabular}{lcccc}
\hline \multicolumn{1}{c}{ The Type of Branches } & $\begin{array}{c}\text { Preschool } \\
(\mathbf{f})\end{array}$ & $\begin{array}{c}\text { Primary } \\
\text { School } \\
(\mathbf{f})\end{array}$ & $\begin{array}{c}\text { Secondary School } \\
\text { (f) }\end{array}$ & $\begin{array}{c}\text { High Schools } \\
\text { (f) }\end{array}$ \\
\hline Preschool Teacher & 1 & & & \\
\hline Primary School Teacher & 6 & 10 & 5 \\
\hline Informatics Teacher & & 4 & 2 \\
Science Teacher & & & 2 \\
\hline Physics Teacher & & & 1 \\
Computer Teacher & & & 1 \\
Electric-Electronics Teacher & & $\mathbf{1 4}$ & $\mathbf{1 1}$ \\
Mathematics & $\mathbf{6}$ & & \\
Transportation & $\mathbf{1}$ & & \\
\hline Total & & & & \\
\hline
\end{tabular}


Teachers who carry robotic-coding and electronics studies are classified according to their branches and numbers at Table 5. When Table 5 is examined, pre-school teachers applied robotic - coding and electronic applications in pre-school. Primary school teachers undertook these applications in primary school. IT teachers mostly implement these practices in secondary schools. It is seen that different branches of high school teachers undertake these applications, but most physics teachers applied the practices. Answers given to the question of "If robotics-coding and electronics practices cannot be applied at your school, what are the reasons for that?" are shown at Table 6.

Table 6. The Reasons for Failure of Robotic-Coding Studies

\begin{tabular}{|c|c|c|c|c|c|}
\hline & Preschool & $\begin{array}{l}\text { Primary } \\
\text { School }\end{array}$ & $\begin{array}{l}\text { Secondary } \\
\text { School }\end{array}$ & $\begin{array}{l}\text { High } \\
\text { School }\end{array}$ & Total \\
\hline Cods & (f) & (f) & (f) & (f) & (f) \\
\hline $\begin{array}{l}\text { The lack of personnel (Received } \\
\text { education or voluntary) }\end{array}$ & 3 & 8 & 2 & 7 & 20 \\
\hline $\begin{array}{l}\text { The lack of materials, financial } \\
\text { impossibilities }\end{array}$ & 0 & 1 & 2 & 2 & 5 \\
\hline $\begin{array}{l}\text { The lack of workshop-classroom, the } \\
\text { insufficiency of physical conditions }\end{array}$ & 0 & 4 & 3 & 3 & 10 \\
\hline Students' negative attitudes & 0 & 0 & 1 & 0 & 1 \\
\hline $\begin{array}{l}\text { The thought that the curriculum is } \\
\text { sufficient }\end{array}$ & 0 & 0 & 2 & 1 & 3 \\
\hline No answer or irrelevant answer & 1 & 1 & 2 & 3 & 7 \\
\hline Total number of schools $(\mathbf{N})$ & 4 & 14 & 18 & 16 & 52 \\
\hline
\end{tabular}

Table 6 is constituted according to reasons of failure of expected practices. When looked at preschool institutions it has been seen that three schools answered as "lack of personnel". In primary schools, while eight schools answered as lack of personnel, four schools, on the other hand, showed insufficiencies of physical conditions as reason of failure of practices. At secondary schools, various reasons have been demonstrated. One of these schools stated that students do not want to participate in these applications. One of the high schools stated that the students found the curriculum lessons sufficient.

Some of schools' administrator answers to the question that took place at the table 6 are given below by direct citation:

Administrator by $\mathrm{Sch}_{15}$; "The lack of educated teachers and lack of classrooms."

Teacher by $\mathrm{Sch}_{46}$; "We had coding studies at 2017-2018 academic year. This year, we do not have a place to carry out study since our all rooms were transformed to classroom (computer laboratory included).

Table 7 shows the answers given to the question of "What are the coding programs and electronicsrobotics tools used at your school?" 
Table 7. Determination of coding programs and electronics-robotics tools used at schools.

\begin{tabular}{|c|c|c|c|c|c|c|}
\hline & & $\begin{array}{l}\text { Preschool } \\
\text { f }\end{array}$ & $\begin{array}{l}\text { Primary School } \\
\text { f }\end{array}$ & $\begin{array}{l}\text { Secondary } \\
\text { School } \\
\text { f }\end{array}$ & $\begin{array}{l}\text { High } \\
\text { School } \\
\text { f }\end{array}$ & $\begin{array}{l}\text { Total } \\
\mathbf{f}\end{array}$ \\
\hline \multirow{7}{*}{ 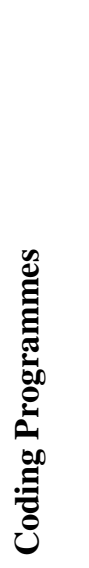 } & Scratch & 0 & 3 & 10 & 3 & 16 \\
\hline & Snap4arduino & 0 & 2 & 2 & 2 & 6 \\
\hline & mBlock & 0 & 2 & 6 & 3 & 11 \\
\hline & Arduino ide & 0 & 1 & 6 & 6 & 13 \\
\hline & S4A & 0 & 0 & 4 & 1 & 5 \\
\hline & App Inventor & 0 & 0 & 4 & 2 & 6 \\
\hline & Thunkable & 0 & 0 & 1 & 0 & 1 \\
\hline \multirow{5}{*}{ 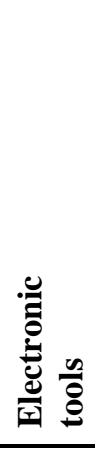 } & Arduino & 0 & 2 & 8 & 7 & 17 \\
\hline & $\begin{array}{l}\text { Breadboard } \\
\text { applications }\end{array}$ & 0 & 2 & 6 & 6 & 14 \\
\hline & Sensor applications & 0 & 1 & 7 & 7 & 15 \\
\hline & 3D printer & 0 & 0 & 3 & 1 & 4 \\
\hline & Solder set & 0 & 1 & 4 & 5 & 10 \\
\hline \multirow{4}{*}{ 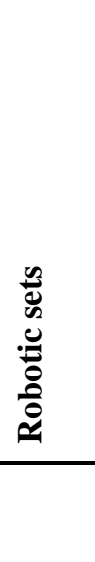 } & Arduino starter set & 0 & 2 & 6 & 5 & 13 \\
\hline & $\begin{array}{l}\text { Robotic education set } \\
\text { (Cloud Board, 3D } \\
\text { Robolab card, mBot, } \\
\text { OBot, Rbot vd) }\end{array}$ & 0 & 1 & 4 & 2 & 7 \\
\hline & $\begin{array}{l}\text { Advanced level robot } \\
\text { set } \\
\text { (LEGO, } \\
\text { Robotics) }\end{array}$ & 0 & 0 & 2 & 1 & 3 \\
\hline & $\begin{array}{l}\text { Total number of } \\
\text { schools }(\mathbf{N})\end{array}$ & 4 & 14 & 18 & 16 & 52 \\
\hline
\end{tabular}

When coding programs that schools used are examined, it is seen that scratch is much more preferred at primary and secondary schools while Arduino ide is more commonly preferred at the high schools. When electronic tools that schools used are examined, it was determined that primary schools preferred Arduino and breadboard applications more than others do; secondary schools and high schools have given more place to Arduino applications at secondary schools and high schools. When robotic sets that schools used are examined, it is seen that primary schools, secondary schools and high schools use Arduino starter sets generally.

\section{Findings about Determination of Schools' Needs}

Table 8 shows the answers given to the question of "What are the expectations of your school from DoNE in terms of robotic-coding and electronic practices?" 
Table 8. Schools' expectation from DoNE

\begin{tabular}{|c|c|c|c|c|c|}
\hline & $\begin{array}{l}\text { Preschool } \\
\text { f }\end{array}$ & $\begin{array}{l}\text { Primary } \\
\text { School } \\
\text { f }\end{array}$ & $\begin{array}{l}\text { Secondary } \\
\text { School } \\
\text { f }\end{array}$ & $\begin{array}{l}\text { High } \\
\text { School } \\
\text { f }\end{array}$ & $\begin{array}{l}\text { Total } \\
\mathbf{f}\end{array}$ \\
\hline $\begin{array}{l}\text { Participating in teacher } \\
\text { seminar programmes }\end{array}$ & 4 & 10 & 3 & 7 & 24 \\
\hline $\begin{array}{l}\text { Providing } \quad \text { equipment, } \\
\text { material }\end{array}$ & 1 & 4 & 8 & 4 & 16 \\
\hline $\begin{array}{l}\text { Establishing } \quad \text { Workshop, } \\
\text { Laboratory }\end{array}$ & 0 & 8 & 4 & 5 & 17 \\
\hline Giving student educations & 1 & 1 & 1 & 2 & 4 \\
\hline $\begin{array}{l}\text { Establishing student clubs } \\
\text { throughout the district (to } \\
\text { those who are successful) }\end{array}$ & 0 & 1 & 1 & 1 & 3 \\
\hline $\begin{array}{l}\text { Carrying out parents' } \\
\text { seminars }\end{array}$ & 0 & 0 & 1 & 0 & 1 \\
\hline Financial support & 0 & 0 & 3 & 3 & 6 \\
\hline Teacher and student coaching & 1 & 0 & 3 & 1 & 4 \\
\hline Total number of schools (N) & 4 & 14 & 18 & 16 & 52 \\
\hline
\end{tabular}

When the findings in Table 8 are examined; it was observed that pre-school, primary and high schools stated that they needed teacher seminars on these applications. In secondary schools, it was determined that there is a need to overcome the lack of material.

Some of schools' administrator and teachers' answers to the question that took at the table 8 are given below by direct citation:

Administrator by Sch02 "Increasing of education toward to these fields"

Administrator by $\mathrm{Sch}_{03}$ "carrying out the necessary studies to show the importance of coding to teachers, administrators, students and parents"

Teacher by $\mathrm{Sch}_{24}$ "Informatics Technologies class needs to be renewed for more sophisticated applications to work such as Android Studio, Unity 3D. In addition, 3D printers are needed to support Arduino studies."

Administrator by $\mathrm{Sch}_{52}$ "Support can be provided in order to studies carried out"

Administrator by $\mathrm{Sch}_{37}$ "You can be supporter about establishing coding workshop and educators being tasked with."

\section{Findings about Determination of Schools' Plans}

Table 9 shows the answers given to the question of "What are the future plans of teachers who participate in robotics, coding and electronics studies?" 
Table 9. The future plans of teachers who participate in robotics, coding and electronics studies

\begin{tabular}{|c|c|c|c|c|c|}
\hline & reschool & Primary & Secondary & High & Total \\
\hline & $\mathbf{f}$ & f & $\mathbf{f}$ & f & f \\
\hline $\begin{array}{l}\text { Participating in seminars and in } \\
\text { teacher trainings }\end{array}$ & 9 & 37 & 40 & 40 & 126 \\
\hline $\begin{array}{l}\text { Establishing laboratory or } \\
\text { atelier at our school }\end{array}$ & 0 & 9 & 8 & 10 & 27 \\
\hline $\begin{array}{l}\text { Buying robotic education set } \\
\text { for our school }\end{array}$ & 1 & 10 & 11 & 8 & 30 \\
\hline $\begin{array}{l}\text { Participating in project } \\
\text { competitions }\end{array}$ & t 0 & 8 & 9 & 7 & 24 \\
\hline We have no plan & 0 & 0 & 1 & 0 & 1 \\
\hline Total number of schools $(\mathrm{N})$ & 4 & 14 & 18 & 16 & 52 \\
\hline
\end{tabular}

Table 9 shows that teachers at all school levels want to attend seminars on coding and robotics in the future. It was also observed that primary and secondary schools stated that they wanted to buy robotic education sets. On the other hand, high schools stated that they plan to establish a robotics and coding laboratory or atelier.

\section{Findings about the Contributions of Robotic-Coding and Electronics Practices to the Education}

Table 10 shows answers given to the question of "What are the contributions of robotic-codingelectronics practices to the education given at schools?"

Table 10. Coding, robotics and electronics' studies' contributions to the education given at schools

\begin{tabular}{|c|c|c|c|c|c|}
\hline & Preschool & $\begin{array}{l}\text { Primary } \\
\text { School }\end{array}$ & $\begin{array}{l}\text { Secondary } \\
\text { School }\end{array}$ & $\begin{array}{l}\text { High } \\
\text { School }\end{array}$ & Total \\
\hline & $\mathbf{f}$ & f & f & $\mathbf{f}$ & $\mathbf{f}$ \\
\hline $\begin{array}{l}\text { Improving high-level skills (algorithmic, } \\
\text { creative, analytical thinking and problem } \\
\text { solving, research and questioning skills). }\end{array}$ & 0 & 4 & 6 & 4 & 14 \\
\hline Supporting inter-disciplinary studies & 0 & 1 & 1 & 0 & 2 \\
\hline $\begin{array}{l}\text { Increasing the interest, motivation and } \\
\text { awareness toward to the school in a positive } \\
\text { direction }\end{array}$ & 1 & 1 & 2 & 2 & 6 \\
\hline $\begin{array}{l}\text { Being aware of technological developments } \\
\text { and using it in a conscious manner }\end{array}$ & 1 & 0 & 3 & 2 & 6 \\
\hline $\begin{array}{l}\text { Supporting individual improvements of } \\
\text { teachers and students, constituting } \\
\text { competition }\end{array}$ & 0 & 1 & 0 & 2 & 3 \\
\hline $\begin{array}{l}\text { Increasing the success of lesson, enriching } \\
\text { lessons }\end{array}$ & 0 & 0 & 1 & 2 & 3 \\
\hline
\end{tabular}




\begin{tabular}{llllll}
\hline $\begin{array}{l}\text { Preparing students to the future, providing } \\
\text { the development of country }\end{array}$ & 1 & 0 & 2 & 3 & 6 \\
\hline $\begin{array}{l}\text { It has no contribution to central exams and } \\
\text { school education }\end{array}$ & 0 & 0 & 2 & 0 & 2 \\
\hline $\begin{array}{l}\text { There is no study carried, we couldn't } \\
\text { determine }\end{array}$ & 0 & 1 & 1 & 1 & 3 \\
\hline $\begin{array}{l}\text { Providing imagine-design-generate cycle } \\
\text { with possibility for practicing. }\end{array}$ & 0 & 1 & 2 & 4 & 7 \\
\hline Empty & 2 & 7 & 4 & 5 & 18 \\
\hline Total number of school (N) & $\mathbf{4}$ & $\mathbf{1 4}$ & $\mathbf{1 8}$ & $\mathbf{1 6}$ & $\mathbf{5 2}$ \\
\hline
\end{tabular}

When looked at Table 10, it has been given place to what contributions of robotic-coding and electronics studies to the education given at schools are. When Table 10 is examined; in the responses from primary, secondary and high schools, the opinion that these applications contribute to the highlevel skills of students is dominant. All schools are of the opinion that these practices generally increase students' interest, motivation and awareness towards the school. They are also of the opinion that it contributes to the awareness of technological developments and to use technology more consciously. Seven schools at the level of primary school have left this question "empty". While two schools at the level of secondary schools gave answers as "It has no contribution to central exams and school education", four schools at the level of high schools, on the other hand, have answered as "providing possibility for practicing with imagine-design-generate cycle".

Some of schools' administrator and the teacher answers to the question that took place at the table 10 are given below by direct citation:

Teacher by $\mathrm{Sch}_{50}$ "It primarily works up observable excitement and interest among students. It makes us feel to improve ourselves on the name of meeting their demands. Almost every day a student comes with an idea of project. Its contribution to lesson in short term is not possible but at middle and long term, it might be. I estimate that students' learning motivation is to increase as long as they look at subjects at lessons as materials, resources for a concrete project. (However, weekly syllabus does not leave time to students for studying on the name of STEM. Ministry of National Education (MoNE) aims a reform on this subject but in the meantime STEM studies can be opened up as a course at the scope of STC (Support and Training Courses)"

Administrator by $\mathrm{Sch}_{32}$ "It is thought that coding studies at school are effective in the improvement of students' different thinking skills and imaginations. At the same time, it influences success at the numerical lessons in a positive direction."

\section{DISCUSSION AND CONCLUSION}

When literature review is carried, it is seen that practices including robotic-coding and electronics components have an important potential to influence the nature of engineering and science education at the each level of education from primary school to university (Mataric, 2004; Alimisis, 2013). At many schools on the world, robotics and coding are included at education programs and taught to students at their early age (Ospennikova, Ershov \& Iljin, 2015; Ronsivalle, Boldi, Gusella, Inama \& Carta, 2019). At this scope, targets regarding robotic coding in our country are added to recent programs (Sayın \& Seferoğlu, 2016). Nevertheless, these studies do not take shape according to only education program but also to teacher, students, school policies and equipment of schools.

In our study, it was seen that the practices of robotic-coding and electronics of schools that we determined the current situation were carried in the extracurricular activities rather than the scope of formal education. The reason of this can be, as sufficient number of students were not attend at 
workshops. Another result we obtained from the determination of current situation is that it was seen that our schools' studies focused on robotics, coding and technology were concentrated on at the last two years. The reason of this can be as those teachers do not have sufficient knowledge and skills about this new emergent field and those workshops are established at schools lately. Researches carried out show that only a few teachers have experience and skills to carry this kind of activities and that who those have skills about technology, at best situations, know how to use some computer applications (Bers, Ponte, Juelich, Viera \& Schenker, 2002). In addition, that these educations were not given yet at the preschool period that we obtained from current situation determination is a remarkable topic. However, it is said that giving robotic education to children at an early age is very important, that children should be introduced to robotic coding at an early age, and robotic coding activities should be included in education curricula along with pre-school education (Tunç \& Kıncal, 2018).

Robotic coding and electronic practices in primary schools have been undertaken by primary school teachers and in secondary schools by science and IT teachers. In high schools, it is seen that more branch teachers are undertaken. In the responses received at the schools, it was shown that the students did not demand this as the reason for the low implementation of the schools. However, studies demonstrate that robotic coding is in the direction that middle school students find the activities enjoyable and interesting; they are willing to participate in the activities and think that they contribute positively to their personal development (Kasalak, 2017). The opinion of teachers and administrators that there is no student demand contradicts these results. Such an opinion may be because school administrators and teachers are afraid of this technological application and do not consider themselves sufficient. Explaining this result, Mihc1 Türker and Pala (2018) stated in their study that an indispensable part of the teachers did not consider themselves sufficient in coding or only at a basic level.

According to the study, it is seen that the expectations of schools from district DoNE are in a manner to improve themselves and schools according to answers of schools participating in the study. It is seen that support is sought to get efficient result by reaching to large mass, not limited only with school by demanding teacher and student coaching or parents' seminar.

When it is looked at future plans of teachers participated in the study about robotic-coding and electronics, it is seen that schools that are insufficient on these subjects want to participate in educations expected to be given in the body of province or district. It is seen that, on the other hand, those who received this education want to participate in competitions or establish laboratory or coding workshops. According to Bütüner and Dündar (2018), it was seen that teachers in charge at schools that received education want to contribute to schools in which they want to advance the education by being more motivated and removing prejudices.

When answers given to the question about what contribution of robotic-coding and electronics practices to the education are examined, it was concluded that it would improve the top level skills, the interest and awareness toward to school would increase, in addition technology would be used in a more conscious way by being followed closely. According to Çankaya, Durak and Yünkül (2017), it was concluded that positive results were obtained from students who received education at the result of programming training with robots and it increased their motivation. Kirkan (2018) found out that basic robotics education has positive impacts on solving problem skills of seven highly talented science students at the result of study art centers and stated that students continue producing products based on robotics after education.

Conclusions below were reached in the study:

$\checkmark$ It was found that robotic, coding and electronic practices were applied mostly at secondary school level among the examined schools. In addition, it is determined that coding lessons are preferred more than robotic and other electronic applications.

$\checkmark$ It is seen that secondary schools have more place in terms of places in which extracurricular activities can be carried at schools. It is also seen that they are more equipped compare with 
schools at other levels in terms of support education rooms, number of libraries, number of laboratories and coding workshops.

$\checkmark$ When the number of schools that carry this kind of studies is examined, it is seen that higher numbers are reached at secondary schools.

$\checkmark$ When looked at the situations of teachers received education about robotics, coding and electronics, it is seen that there are more teachers who receive education at secondary schools again.

$\checkmark$ When the branches of teachers who carry out robotic-coding and electronics' studies are examined, it is seen that informatics teachers at the secondary schools and physics teachers at the high schools carry out the studies.

$\checkmark$ As reason of failure of practices expected to be carried out is shown as primarily lack of personnel, insufficiency of physical conditions and then that there is not enough materials.

$\checkmark$ When coding programs used by schools are examined, it is seen that scratch and arduino ide are preferred primarily. When the electronic devices used by schools are examined, it is seen that arduino applications were given place and that they used Arduino starter sets predominantly as robotic set.

$\checkmark$ It is seen that schools await for support from district DoNE about arranging teacher seminars, establishing workshop-laboratory, giving educations to students, coaching teachers and students and providing financial support.

$\checkmark$ When looked at teachers' expectations from future about topic, it is seen that they predominantly want to participate in seminars about subject, workshops and laboratories to be established at their schools and financial support to be provided for materials.

$\checkmark$ They stated that these kinds of studies at throughout of schools improve students' high level skills; increase interest, motivation, awareness to school in a positive manner; contribute to their awareness of technological developments and to use it in a more conscious way; give possibility them to practice engineering skills and particularly have important contribution to preparing of students and the country for future.

Findings in relevant literature show common trait with opinions emergent at the result of research carried. It is thought that use of practices of robotics, coding and electronics in lessons or extracurricular activities will provide a more effective learning environment. Common opinion of all the schools that received or want to receive education in these fields is that robotic and coding practices have positive impact on students' academic success, attitude and motivation. In addition, that this field is supported by more education and prepared guidebook is among needs.

It has been concluded that schools are showing willingness for learning about robotic-coding and electronics but education and its possibilities are insufficient. It has seen that some teachers are prejudiced against robotic coding but this will disappear along with the education to be received. From point of view of research conclusions, it might be offered that education is to be given to educators, protectors and students at schools and that, together with this, they are provided with environments in which they can carry out these educations.

\section{Bilgilendirme / Acknowledgement:}

1- Araştırmacıların katkı oranı eşittir.

2- Makalenin yazarları arasında çıkar çatışması bulunmamaktadır.

3- Makaledeki veriler 2019 yılında toplanmış ve değerlendirilmiştir.

4- Bu makalede araştırma ve yayın etiğine uyulmuştur. 


\section{REFERENCES}

Alimisis, D. (2013). Educational robotics: Open questions and new challenges. Themes in Science and Technology Education, 6(1), 63-71.

Alsoliman, B. S. H. (2018). The utilization of educational robotics in Saudi schools: potentials and barriers from the perspective of Saudi teachers. International Education Studies, 11(10), $105-111$.

Bers, M. U., Ponte, I., Juelich, C., Viera, A., \& Schenker, J. (2002). Teachers as designers: Integrating robotics in early childhood education. Information Technology in Childhood Education Annual, 2002(1), 123-145.

Bütüner, R. \& Dündar, Ö. (2018). Kodlama eğitiminde robot kullanımı ve robotik kodlama eğitici eğitiminde öğretmenlerin tecrübe ve görüşlerinin alınması. Human Society and Education in the Changing World, 278.

Çankaya, S., Durak, G. \& Yünkül, E. (2017). Robotlarla programlama eğitimi: öğrencilerin deneyimlerinin ve görüşlerinin incelenmesi. Turkish Online Journal of Qualitative Inquiry (TOJQI), 8(4), 428-445.

EARGED (2011). MEB 21. yüzyıl öğrenci profili. Retrieved from from http://www.meb.gov.tr/earged/earged/21.\%20yy_og_pro.pdf on October 13, 2019.

Eguchi, A. (2012). Educational robotics theories and practice: tips for how to do it right. In B. Barker, G. Nugent, N. Grandgenett \& V. Adamchuk (Eds.), Robots in K-12 Education: A New Technology for Learning (pp. 1-30). Hershey, PA: IGI Global. doi:10.4018/978-1-46660182-6.ch001.

Elkind, D. (2008). Forward. In M.U. Bers, (Ed.). Block to Robots. (pp. xi-xiv). New York, NY: Teachers College Press.

Ettershank, M., Nel, H., \& Solms, S.V. (2017). Integration of a robotics programme into a South African secondary school curriculum: A case study. IEEE AFRICON, 701-706.

Gelen, İ. (2017). P21-Program ve öğretimde 21. Yüzyıl beceri çerçeveleri (ABD uygulamaları). Disiplinlerarası Eğitim Araştırmaları, 1(2), 15-29.

Göksoy, S., \& Yılmaz, İ. (2018). Bilişim teknolojileri öğretmenleri ve öğrencilerinin robotik ve kodlama dersine ilişkin görüşleri. Düzce Üniversitesi Sosyal Bilimler Enstitüsü Dergisi, 1, 178 - 196.

Kasalak, İ. (2017). Robotik kodlama etkinliklerinin ortaokul öğrencilerinin kodlamaya ilişsin özyeterlik algılarına etkisi ve etkinliklere ilişskin ögrenci yaşantıları. Yayınlanmamış doktora tezi, Hacettepe Üniversitesi, Eğitim Bilimleri Enstitüsü, Ankara.

Kay, J. S., \& Moss, J. G. (2012). Using robots to teach programming to K-12 teachers. In 2012 Frontiers in Education Conference Proceedings (pp. 1-6). IEEE.

Kay, J. S., Moss, J. G., Engelman, S., \& McKlin, T. (2014). Sneaking in through the back door: introducing K-12 teachers to robot programming. In Proceedings of the 45th ACM technical symposium on Computer science education (pp. 499-504). ACM.

Kırkan, B. (2018). Üstün yetenekli ortaokul öğrencilerinin proje tabanlı temel robotik eğitim süreçlerindeki yaratıcı, yansitıcı düşünme ve problem çözme becerilerine ilişkin davranışlarının ve görüşlerinin incelenmesi. Yayınlanmamış yüksek lisans tezi, Başkent Üniversitesi, Eğitim Bilimleri Enstitüsü, Ankara.

Mataric, M. J. (2004). Robotics education for all ages. In Proc. AAAI Spring Symposium on Accessible, Hands-on AI and Robotics Education. Retrieved from https://www.aaai.org/Papers/Symposia/Spring/2004/SS-04-01/SS04-01-004.pdf on October $1,2019$. 
Mihc1 Türker P. ve Pala F.K. (2018). Opinions of secondary school students, teachers and parents about coding. Elementary Education Online, 17(4), 2013-2029.

MoNE (2018). Bilgisayar bilimi dersi kur 1-2 ögretim programı. Retrieved from from http://mufredat.meb.gov.tr/Dosyalar/2018120203611364BILGISAYAR\%20BILIMI\%20DE RSI\%20OGRETIM\%20PROGRAMI.pdf on September 25, 2019.

Ospennikova, E., Ershov, M. \& Iljin, I. (2015). Educational robotics as an inovative educational technology. Procedia-Social and Behavioral Sciences, 214, 18-26.

Özden, M.Y. \& Durdu, L. (2016). Nitel araştırma yöntemleri, Ankara: Anı Yayıncılık.

Pinto, A. \& Escudeiro, P. (2014). The use of Scratch for the development of 21st century learning skills in ICT. In 18-21 Jun. 2014, 9th Iberian Conference on Information Systems and Technologies (CISTI) (pp. 1-4). IEEE.

Ronsivalle, G. B., Boldi, A., Gusella, V., Inama, C., \& Carta, S. (2019). How to implement educational robotics' programs in Italian schools: a brief guideline according to an instructional design point of view. Technology, Knowledge and Learning, 24(2), 227-245.

Sayın, Z. \& Seferoğlu, S. S. (2016). Yeni bir 21. yüzyıl becerisi olarak kodlama eğitimi ve kodlamanın eğitim politikalarına etkisi. Akademik Bilişim Konferansı 2016, 3-5 Şubat 2016, Adnan Menderes Üniversitesi, Aydın.

Şenol, A. K., \& Büyük, U. (2015). Robotik destekli fen ve teknoloji laboratuvar uygulamaları: ROBOLAB. Journal of Turkish Studies, 10(3), 213-236.

Sırakaya, M. (2018). Kodlama eğitimine yönelik öğrenci görüşleri. Ondokuz Mayls Üniversitesi Eğitim Fakültesi Dergisi, 37(2), 79-90.

Şişman, B. \& Küçük, Ş. (2018). Öğretmen adaylarının robotik programlamada akış, kaygı ve bilişsel yük seviyeleri. Eğitim Teknolojisi, Kuram ve Uygulama, 8(2), 108-124.

Tunç, Y. \& Kıncal R. Y. (2018 Mayıs). Okul öncesinde kodlamanın önemi ve kodlama eğitimlerinde kullanılan araç ve uygulamaların incelenmesi. II. Uluslararası Multidispliner Çalışmaları Kongresinde sunulan bildiri. 7-8 Aralık 2018, Çukurova Üniversitesi, Adana.

Turiman, P., Omar, J., Daud, A. M., \& Osman, K. (2012). Fostering the 21st century skills through scientific literacy and science process skills. Procedia-Social and Behavioral Sciences, 59, 110-116.

Yıldırım, A., \& Şimşek, H. (2008). Sosyal bilimlerde nitel araştırma yöntemleri. Ankara: Seçkin Yayınc1lik. 